\title{
TINDAK PIDANA KETERBUKAAN INFORMASI PUBLIK DI INDONESIA \\ SEBUAH KAJIAN PERBANDINGAN SISTEM PEMIDANAAN DI NEGARA ASING THAILAND DAN JEPANG
}

\author{
Sitta Saraya \\ Fakultas Hukum, Universitas Selamat Sri (UNISS) Kendal \\ sittalaw@gmail.com
}

\begin{abstract}
Abstrak
Indonesia merupakan negara hukum berdasarkan Pancasila sebagai landasan idiil dan Undang-Undang Dasar Negara Republik Indonesia Tahun 1945 sebagai landasan konstitusional yang bertujuan untuk mewujudkan tata kehidupan bangsa yang sejahtera, aman, tertib, dan berkeadilan hukum. Tujuan penelitian ini adalah untuk mengetahui perumusan pidana dan pemidanaan dalam Undang-Undang Nomor 14 Tahun 2008 Tentang Keterbukaan Informasi Publik, dan pelaksanaan tindak pidana keterbukaan informasi publik dalam kajian perbandingan sistem pemidanaan tindak pidana keterbukaan informasi publik di negara Thailand dan Jepang? Metode penelitian yang digunakan dalam penelitian ini adalah yuridis normatif. Adanya Undang-Undang No 14 Tahun 2008 yang mulai berlaku pada 1 Mei 2010 diharapkan agar semua badan publik memberikan dan membuka akses informasi publik. Hasil dari penelitian ini dapat disimpulkan bahwa perumusan pidana sesuai dengan Undang-Undang Nomor 14 Tahun 2008 pidana yang dikenakan adalah pidana penjara sebagai pidana pokoknya dengan maksimal khusus satu tahun atau ada alternatif lainnya yaitu pidana denda atau hakim berhak menjatuhi kedua pidana tersebut secara bersamaan. Tindak pidana infomasi publik di Jepang dapat dikenakan pidana penjara juga disertai dengan kerja paksa atau dengan adanya alternatif pidana denda sebagai pengganti pidana pokok berupa pidana penjara dan kerja paksa. Sedangkan tindak pidana keterbukaan informasi publik di Thailand dapat dikenakan sanksi pidana yang dijatuhkan berorientasi pada sistem pidana maksimal khusus 1 (satu) tahun penjara atau berupa sanksi denda dan bisa juga dengan alternatif sanksi pidana yakni dijatuhi sanksi keduanya baik berupa penjara dan denda.

Kata Kunci:Tindak Pidana; Keterbukaan Informasi Publik; Perbandingan Sistem Pemidanaan.
\end{abstract}




\title{
CRIME OF PUBLIC INFORMATION IN INDONESIA A COMPARATIVE STUDY PUNISHMENT SYSTEM IN FOREIGN COUNTRIES THAILAND AND JAPAN
}

\author{
Sitta Saraya \\ Law Faculty, Universitas Selamat Sri (UNISS) Kendal \\ sittalaw@gmail.com
}

\begin{abstract}
Indonesia is a constitutional state based on Pancasila as an ideal basis and the Constitution of the Republic of Indonesia Year 1945 as the constitutional basis aimed toward improved life of the nation that is prosperous, secure, orderly, and legal justice. The purpose of this study was to determine the formulation of criminal and criminal prosecution under Law No. 14 of 2008 on Public Information, and execution of the crime of public disclosure in the criminal system comparative study of public disclosure of criminal acts in the country of Thailand and Japan? The method used in this research is normative. The existence of Act No. 14 of 2008 which came into force on May 1, 2010 it is expected that all public bodies to provide and open access to public information. The results of this study can be concluded that the formulation of the criminal offense according to Law No. 14 of 2008 criminal imposed is imprisonment as maximum punishment principle with a special one-year or are there other alternatives that criminal penalties or criminal judges are entitled fell on both simultaneously. The criminal act of public information in Japan may be subject to imprisonment is also accompanied by forced labor or the existence of alternative criminal penalty in lieu of the principal form of imprisonment and forced labor. While the crime of public disclosure in Thailand could be subject to criminal sanctions imposed penal system oriented specialty maximum of 1 (one) year in prison or be fined and could also alternatively sanctioned criminal sanctions which are both in the form of imprisonment and a fine.

Keywords: Crime; Public Information; Comparison Punishment System.
\end{abstract}




\section{Pendahuluan}

\section{A. Latar Belakang}

Tindak pidana dalam UndangUndang Keterbukaan Informasi Publik membutuhkan suatu upaya yang sistematis untuk dapat mencapai tujuannya. Upaya yang sistematis ini dilakukan dengan mempergunakan segenap unsur yang terlibat di dalamnya sebagai suatu kesatuan dan saling berhubungan (interelasi), serta saling mempengaruhi satu sama lain. Upaya yang demikian harus diwujudkan dalam sebuah sistem yang bertugas menjalankan penegakan hukum pidana tersebut, yaitu Sistem Peradilan Pidana (Criminal Justice System) yang pada hakikatnya merupakan "sistem kekuasaan menegakkan hukum pidana".

Berkaitan dengan hukum pidana, banyak sekali ranah kehidupan berbangsa dan bernegara terutama yang berkaitan dengan peraturan Perundang-undangan yang memuat ketentuan tentang hukum pidana, dan banyak sekali penyelesaian kasus sengketa melalui jalur pidana. Hukum merupakan sesuatu yang menjadi kebutuhan masyarakat, untuk memberikan petunjuk tingkah laku kepada manusia guna menjalani hidupnya. Hukum merupakan pencerminan watak dan kehendak manusia mengenai bagaimana masyarakat itu dibina dan diarahkan. Arah dan pembinaan hukum agar tercapai kehidupan masyarakat yang tertib, aman, dan damai, serta guna mewujudkan keadilan berbangsa dan bernegara. Pidana adalah salah satu dari sekian sanksi yang bertujuan untuk menegakkan berlakunya norma. Pelanggaran norma yang berlaku dalam masyarakat menimbulkan perasaan tidak senang

1 Barda Nawawi Arief, Masalah Penegakan Hukum dan Kebijakan Penanggulangan Kejahatan, Citra Aditya Bakti, Bandung, 2001, hlm., 28. yang dinyatakan dalam pemberian sanksi tersebut. $^{2}$

Informasi merupakan kebutuhan mendasar bagi setiap orang untuk mengembangkan kepribadian di lingkungan soasialnya sehingga hak untuk memperoleh informasi merupakan hak asasi manusia yang wajib untuk dilindungi oleh Pemerintah. Sesuai yang di amanahkan Undang-Undang Dasar 1945 pasal 28F yang berbunyi setiap orang berhak untuk berkomunikasi dan memperoleh informasi untuk mengembangkan pribadi dan lingkungan sosilanya, serta berhak untuk mencari, memperoleh, memiliki, menyimpan, mengolah dan menyampaikan informasi dengan menggunakan segala jenis saluran yang tersedia. ${ }^{3}$

Sesuai dengan prinsip keterbukaan dalam negara demokrasi yang mengharuskan Penyelenggara Negara membuka diri terhadap hak masyarakat untuk memperoleh informasi yang benar, jujur, dan tidak diskriminatif mengenai Penyelenggaraan Negara, maka sesuai dengan Peraturan Pemerintah No 61 tahun 2009 tentang keterbukaan informasi diatur mengenai hak dan tanggung jawab serta kewajiban masyarakat dan Penyelenggara negara secara berimbang. Hal ini dimaksudkan agar masyarakat memperoleh perlindungan hukum dalam menggunakan haknya untuk memperoleh dan menyampaikan informasi tentang Penyelenggara Negara. Kebebasan menggunakan hak tersebut haruslah disertai dengan

${ }^{2}$ Sudarto, Kapita Selekta Hukum Pidana, PT. Alumni, Bandung, 2006, hlm., 106.

${ }^{3}$ Arif Widi Fatoni, Penyelesaian Sengketa Keterbukaan Informasi Publik Melalui Ajudikasi Dalam Undang-U No 14 Tahun 2008 Tentang Keterbukaan Informasi Publik, Jurnal Ius Constituendum Vol 4 No 1, 2019, Semarang, Program Pasca Sarjana Universitas Semarang, hlm 80. 
tanggung jawab untuk mengemukakan fakta dan kejadian yang sebenarnya dengan menaati dan menghormati aturanaturan moral yang diakui umum serta hukum dan peraturan perundangundangan yang berlaku. ${ }^{4}$

Tata kelola pemerintahan yang baik, mensyaratkan pemerintahan yang terbuka dan kebebasan memperoleh informasi untuk menjadi salah satu pondasinya. Pemerintahan yang terbuka mensyaratkan adanya lima jaminan, yaitu : pertama hak untuk memantau prilaku pejabat publik dalam menjalankan peranya; kedua hak untuk memperoleh informasi; ketiga hak untuk terlibat dan berpartisipasi dalam proses pembentukan kebijakan publik; keempat kebebasan berekspresi; kelima hak untuk mengajukan keberatan terhadap penolakan atas keempat hak tersebut. ${ }^{5}$

Sejak diberlakukankannya Undang-Undang No 14 Tahun 2008 tentang Keterbukaan Informasi Publik mulai 1 Mei 2010 makin memperluas pengetahuan kita mengenai peraturan perundangundangan di Indonesia. Adanya Undang-Undang No 14 Tahun 2008 tentang Keterbukaan Informasi Publik ini dapat menjadi katalis dalam pemisahan antara informasi yang berhak didapatkan oleh masyarakat dengan informasi yang bersifat rahasia. Diperlukan

${ }^{4}$ Agus Sutiaman, Dadang Sugianan, Jimi Narotama M, Implementasi Kebijakan Keterbukaan Informasi Publik, Jurnal Kajian Komunikasi Vol 1 No 2, 2013, Bandung, Fakultas Ilmu Komunikasi Universitas Padjadajaran, hlm 197.

5 Slamet Haryanto, Kadi Sukarna, Peran Komisi Informasi Publik Dalam Proses Eksekusi Terhadap Putusan Sengketa Informasi Yang Berkekuatan Hukum Tetap Dalam tinjauan Undang-undang No 14 Tahun 2008 Tentang Keterbukaan Informasi Publik, Jurnal Ius Constituendum Vol 2 No 1, 2017, Semarang, Program Pasca Sarjana Universitas Semarang, hlm 98. pengaturan dalam rangka menjamin hak masyarakat untuk mengakses dan mengetahui melalui media. Keterbukaan informasi publik merupakan suatu transparansi akan hasil kinerja badan publik baik seluruh maupun sebagian dananya bersumber dari Anggaran Pendapatan dan Belanja Negara (APBN) dan Anggaran Pendapatan dan Belanja Daerah (APBD). Lahirnya Undang-Undang No 14 Tahun 2008 tentang Keterbukaan Informasi Publik adalah wujud reformasi penyelenggaraan pemerintahan yang perlu disambut dengan optimisme masyarakat akan itikad baik pemerintah untuk menegaskan adanya jaminan transparansi informasi publik. Mekanisme yang mengatur bagaimana publik dapat mengakses informasi publik perlu dirumuskan dan ditetapkan secara baku untuk menjadi acuan bagi badan publik dan masyarakat pengguna informasi publik sesuai dengan kategori badan publik dan informasi publik yang ada, sebab tidak semua informasi dalam bentuk data, fakta dan pesan dapat diakses oleh publik yang dalam Undang-Undang Nomor 14 Tahun 2008 didefinisikan sebagai informasi yang dikecualikan.

Kebebasan dan kemudahan untuk memperoleh informasi adalah sebagai sarana kehidupan berdemokrasi. Untuk itu kebebasan mencari, memperoleh dan menyebarluaskan informasi merupakan hak asasi manusia dan hak konstitusional warga negara yang tidak boleh diabaikan. Hak atas informasi yang merupakan salah satu hak asasi manusia dan menjadi landasan atas pemenuhan hak-hak lain, tidak akanefektif apabila tidak ada keterbukaan dan kemudahan dalam memperoleh informasi yang lebih luas dan tidak terdistorsi, karena keterbukaan informasi merupakan penentuan kadar dan nilai bagi kehidupan demokrasi. 
Keterbukaan informasi sekaligus sebagai perangkat bagi masyarakat untuk mengontrol dan mengawasi setiap langkah penyelenggara negara. Dalam sistem demokrasi yang menyatakan kekuasaan berasal dari rakyat, oleh rakyat untuk rakyat. Maka dengan demikian sudah semestinya rakyat juga berhak mengkritisi dan mengontrol setiap kebijakan yang diambil dan dijalankan oleh pemerintah. ${ }^{6}$

Dengan transparansi informasi dalam melaksanakan kebijakan publik pada lembaga-lembaga publik, maka pemerintah akan mendapatkan kepercayaan dan sokongan dari masyarakat. Sehingga anggaran dana yang dialokasikan untuk penyelenggaraan kebijakan umum dan bagaimana implementasinya di masyarakat dapat secara nyata dilihat semua orang, dengan itu masyarakat bisa memberikan Keterbukaan Informasi, Edwin Nurdiansyah. 151 penilaian yang positip termasuk saran beserta rekomendasi yang membangun dan bukan kecurigaan serta kritik yang hanya menyalahkan tanpa memberikan solusi nyata. ${ }^{7}$

Mengacu kepada standar layanan informasi, masyarakat dengan mudah mendapatkan informasi tetapi tetap dengan etika dan prosedur sebagaimana diatur oleh aturan perundang-undangan. Hal tersebut dimaksudkan agar dapat meminimalisir praktek-praktek menyimpang, seperti pungutan ilegal, pencurian informasi yang

\footnotetext{
6 Eko Noer Kristiyanto, Urgensi Keterbukaan Informasi Dalam Penyelenggaraan Pelayanan Publik, Jurnal Penelitian Hukum De Jure Vol 16 No 2, 2016, Jakarta, Badan Penelitian dan Pengembangan Hukum dan HAM, Kementerian Hukum dan HAM RI, hlm 237-238.

7 Edwin Nurdiansyah,, Keterbukaan Informasi Publik Sebagai Upaya Mewujudkan Transparansi bagi Masyarakat, Jurnal Bhinneka Tunggal Ika Vol 3 No 2, 2016 Palembang, Universitas Sriwijaya, hlm 150151.
}

masuk dalam kategori informasi yang dirahasiakan, penyalahgunaan informasi, plagiarisme, pencurian kekayaan intelektual dan tindakan menyimpang lainnya yang dilakukan pejabat publik dan masyarakat.

\section{B. Permasalahan}

Penelitian perumusan masalah yang diangkat adalah sebagai berikut :

a. Bagaimana perumusan pidana dan pemidanaan dalam Undang-Undang Nomor 14 Tahun 2008 Tentang Keterbukaan Informasi Publik?

b. Bagaimana tindak pidana keterbukaan informasi publik dalam kajian perbandingan sistem pemidanaan tindak pidana keterbukaan informasi publik di Negara Jepang dan Thailand?

\section{Metode Penelitian}

Jenis metode penelitian dalam artikel ini adalah yuridis normatif. Penelitian hukum yuridis normatif adalah suatu proses untuk menemukan suatu aturan hukum, prinsip-prinsip hukum, maupun doktrin-doktrin hukum yang dihadapi. ${ }^{8}$ Dalam penelitian ini hukum diidentifikasikan sebagai norma peraturan atau Undang-Undang (UU), Peraturan Pemerintah (PP). Pendekatan perundangundangan dilakukan dengan cara menelaah semua aturan UndangUndang dan regulasi yang bersangkut paut dengan isu hukum yang sedang ditangani. ${ }^{9}$ Bahan hukum yang digunakan berupa bahan hukum primer dan bahan hukum sekunder. Bahan hukum primer terdiri atas Pancasila dan Undang-Undang Dasar Negara Republik Indonesia Tahun 1945, Kitab

\footnotetext{
${ }^{8}$ Peter Mahmud Marzuki. 2015.
}

Penelitian Hukum, Surabaya. Kencana, hlm 35 ${ }^{9}$ Ibid 
Undang-undang Hukum Pidana (KUHP), Undang-Undang Nomor 39 Tahun 1999 Tentang Hak Asasi Manusia, Undangundang Nomor 14 Tahun 2008 tentang Keterbukaan Informasi Publik, Undang-Undang Nomor 11 Tahun 2008 Tentang Informasi dan Transaksi Elektronik, Undang-Undang Tentang Akses ke Informasi yang berada di badan Pemerintahan (1999) Negara Jepang; Undang-Undang Informasi Resmi (1997) Negara Thailand. Bahan hukum sekunder diperoleh dengan cara studi kepustakaan melalui buku, jurnal, hasil penelitian yang relevan dengan penelitian penulis.

\section{PEMBAHASAN}

\section{a. Perumusan Pidana dan Pemidanaan Dalam Undang- Undang Nomor 14 Tahun 2008 Tentang Informasi Publik.}

Dari ketentuan UndangUndang Nomor 14 Tahun 2008 Tentang Keterbukaan Informasi Publik, dapat diidentifikasikan formulasi sanksi pidana yang berkaitan dengan sistem pemidanaan hukum pidana substantif tersebut dalam dua hal, yaitu;

1. Formulasi jenis (stelsel) sanksi pidana dalam Undang-Undang Nomor 14 Tahun 2008 Tentang Keterbukaan Informasi Publik;

2. Formulasi sistem pola sanksi pidana dalam Undang-Undang Nomor 14 Tahun 2008 Tentang Keterbukaan Informasi Publik.

Menurut Barda Nawawi Arief, "sistem pemidanaan" yang dituangkan perumusannya di dalam Undang-Undang, pada hakikatnya merupakan suatu sistem kewenangan menjatuhkan pidana. ${ }^{10}$

Formulasi ketentuan jenis sanksi hukum pidana dalam Undang-Undang Nomor 14 Tahun 2008 Tentang Keterbukaan Informasi Publik dibandingkan dengan ketentuan sanksi dalam KUHP dapat diketahui sebagai berikut:

a. Pidana pokok berupa pidana kurungan dan pidana denda diformulasikan secara alternatif dan ada pula secara alternatif-kumulatif, seperti tercantum dalam Bab IX Ketentuan Pidana Undang-Undang Nomor 14 Tahun 2008 Tentang Keterbukaan Informasi Publik Pasal 51, Pasal 52, Pasal 53, Pasal 54, Pasal 55 dibawah ini.

Pasal 51 Undang-Undang Nomor 14 Tahun 2008 Tentang Keterbukaan Informasi Publik, seseorang dapat dikenakan pidana jika menggunakan informasi secara melawan hukum, kemudian mengenai penjatuhan sanksi pidana yakni ada alternatif pedoman pemidanaan yakni pidana pokok berupa pidana penjara dengan ketentuan maksimum 1 tahun atau alternatif pidana lainnya yakni dikenakan pidana denda. Pasal 52, pidana yang dijatuhkan berupa pidana kurungan dengan

10 Barda Nawawi Arief, Beberapa Aspek Pengembangan Ilmu Hukum Pidana (Menyongsong Generasi Baru Hukum Pidana Indonesia), Pidato Pengukuhan Guru Besar Ilmu Hukum UNDIP Semarang, 25 Juni 1994. Dalam Penghimpun Soekotjo Hardiwinoto, Kumpulan Pidato Pengukuhan Guru Besar Fakultas Hukum UNDIP Semarang, Badan Penerbit UNDIP, Semarang, Hal.369. 
maksimum kurungan 1

(satu) tahun dan/ atau

dikenakan alternatif

pidana denda maksimum

Pasal 53 , Pasal 54 dan

Pasal 55 Undang-Undang

Keterbukaan Informasi

Publik, dikenai ancaman

pidana pokok penjara maksimum dan adanya alternatif pilihan lain dari pidana pokok yaitu pidana denda.

\begin{tabular}{l}
\multicolumn{2}{c}{ Ketentuan pidan } \\
diatas dapat diketahui \\
bahwa dalam ha \\
perumusan
\end{tabular}
menggunakan gabungan (alternatif-kumulatif) artinya dapat dijatuhkan dua jenis pidana pokok secara bersama-sama yaitu pidana pokok yang dapat dijatuhkan yakni pidana penjara dan pidana denda (strafsoort). Hal ini dapat dilihat dari rumusan "dan/atau". Selain itu ada juga sanksi administrasi yang diatur dalam Pasal 49 Undang-Undang Nomor 14 Tahun 2008 Tentang Keterbukaan Informasi Publik yang menyatakan bahwa:

(1) Putusan

pengadilan tata usaha negara atau pengadilan negeri dalam penyelesaian Sengketa Informasi Publik tentang pemberian atau penolakan akses terhadap seluruh atau sebagian informasi yang diminta berisi salah satu perintah berikut: a. membatalkan putusan Komisi Informasi dan/atau memerintahkan Badan Publik:

1. memberikan sebagian atau seluruh informasi

yang

dimohonkan

oleh

Pemohon

Informasi

Publik; atau

2. menolak memberikan sebagian atau seluruh informasi yang diminta oleh Pemohon

Informasi Publik.

b. menguatkan putusan Komisi Informasi dan/atau memerintahkan Badan Publik:

1. memberikan sebagian atau seluruh informasi

yang diminta oleh Pemohon Informasi Publik; atau

2. menolak memberikan sebagian atau seluruh informasi yang diminta oleh Pemohon Informasi Publik.

(2) Putusan pengadilan tata 


$$
\begin{aligned}
& \text { usaha negara } \\
& \text { atau pengadilan } \\
& \text { negeri dalam } \\
& \text { penyelesaian } \\
& \text { Sengketa } \\
& \text { Informasi Publik } \\
& \text { tentang pokok } \\
& \text { keberatan } \\
& \text { sebagaimana } \\
& \text { dimaksud dalam } \\
& \text { Pasal } 35 \text { ayat (1) } \\
& \text { huruf } b \text { sampai } \\
& \text { dengan huruf } g \\
& \text { berisi salah satu } \\
& \text { perintah berikut: }
\end{aligned}
$$

2. menolak

permohonan

Pemohon

Informasi

Publik; atau

3. memutuskan

biaya

penggandaan

informasi.

4. Pengadilan

tata usaha

negara atau

pengadilan

negeri

\begin{tabular}{|c|c|c|c|}
\hline $\begin{array}{l}\text { Subjek } \\
\text { Tindak } \\
\text { Pidana }\end{array}$ & $\begin{array}{c}\text { Kur } \\
\text { unga } \\
\text { n }\end{array}$ & $\begin{array}{c}\text { Penja } \\
\text { ra }\end{array}$ & Denda \\
\hline $\begin{array}{l}\text { Pasal 51: } \\
\text { Orang }\end{array}$ & & $\begin{array}{l}\text { Max 1 } \\
\text { tahun }\end{array}$ & $\begin{array}{l}\text { Max Rp. } \\
5.000 .000 \\
\text {,00 (lima } \\
\text { Juta } \\
\text { Rupiah) }\end{array}$ \\
\hline $\begin{array}{l}\text { Pasal 52: } \\
\text { Badan } \\
\text { Publik } \\
\text { (sesuai }\end{array}$ & $\begin{array}{c}\text { Max } \\
1 \\
\text { Tahu } \\
\text { n }\end{array}$ & - & $\begin{array}{l}\text { Max Rp. } \\
5.000 .000 \\
\text {,00 (lima } \\
\text { Juta }\end{array}$ \\
\hline
\end{tabular}

memberikan

salinan

putusannya

kepada para

pihak yang

bersengketa.

Untuk perumusan

lamanya pidana

(strafmaat), Undang-

Undang Keterbukaan

Informasi Publik mengatur

secara maksimum khusus,

pidana dapat dikenakan

kepada orang

perseorangan maupun

Badan Publik. Pidana

penjara yang dapat

dikenakan untuk orang

perseorangan adalah

maksimal khusus antara 1

(satu) tahun s/d 3 (tiga)

tahun, sedangkan

dendanya maksimum

khusus antara $\mathrm{Rp}$.

5.000.000,00 (lima juta

rupiah) $\mathrm{s} / \mathrm{d} \quad \mathrm{Rp}$.

20.000.000,00 (dua puluh

juta rupiah). Badan Publik

sendiri dapat dikenakan

maksimal khusus pidana

kurungan paling lama 1

(satu) tahun, sedangkan

dendanya maksimum

khusus sebanyak Rp. 5.000.000,00 (lima juta rupiah).

\section{Skema Sanksi Pidana Sebagai}

\section{Berikut:}




\begin{tabular}{|c|c|c|c|}
\hline $\begin{array}{l}\text { Lampiran } 1 \\
\text { PP No } 1 \\
\text { Tahun } \\
\text { 2010) }\end{array}$ & & & Rupiah) \\
\hline $\begin{array}{l}\text { Pasal } 53 \text { : } \\
\text { Orang }\end{array}$ & - & $\begin{array}{l}\text { Max } 2 \\
\text { Tahun }\end{array}$ & $\begin{array}{l}\text { Max Rp. } \\
10.000 .00 \\
0,00 \\
\text { (Sepuluh } \\
\text { Juta } \\
\text { Rupiah) }\end{array}$ \\
\hline $\begin{array}{l}\text { Pasal } 54 \\
\text { Ayat 1: } \\
\text { Orang } \\
\text { Pasal } 54 \\
\text { Ayat 2: } \\
\text { Orang }\end{array}$ & - & $\begin{array}{l}\text { Max } 3 \\
\text { Tahun }\end{array}$ & $\begin{array}{l}\text { Max Rp. } \\
10.000 .00 \\
0,00 \\
\text { (sepuluh } \\
\text { juta } \\
\text { rupiah) } \\
\text { Max Rp. } \\
20.000 .00 \\
0,00 \text { (dua } \\
\text { puluh juta } \\
\text { rupiah) }\end{array}$ \\
\hline $\begin{array}{l}\text { Pasal 55: } \\
\text { Orang }\end{array}$ & - & $\begin{array}{l}\text { Max 1 } \\
\text { Tahun }\end{array}$ & $\begin{array}{l}\text { Max Rp. } \\
5.000 .000 \\
\text {,00 (lima } \\
\text { Juta } \\
\text { Rupiah) }\end{array}$ \\
\hline
\end{tabular}

Sumber : Penelitian Tesis Penulis Tahun 2012. "Kebijakan

Formulasi Sistem

Pemidanaan Terhadap

Tindak Pidana

Keterbukaan Informasi Publik"11

Dilihat dari skema diatas, apabila pidana denda tidak dapat dipenuhi oleh Badan Publik maupun orang perorangan, dan dalam Undang-Undang Nomor 14 Tahun 2008 tentang Keterbukaan Informasi Publik tersebut tidak mengatur perihal "pidana denda yang tidak terbayar oleh subjek tindak pidana", maka berlaku Pasal 30 angka 2 KUHP, "jika denda tidak

\footnotetext{
${ }^{11}$ Sitta Saraya. 2012. Kebijakan Formulasi
} Sistem Pemidanaan Terhadap Tindak Pidana Keterbukaan Informasi Publik.Tesis Penulis.Magister Hukum Undip Jurusan Sistem Peradilan Pidana. dibayar, lalu diganti dengan kurungan", dan kurungan yang dimaksud adalah kurungan pengganti. Pasal 30 angka 3 KUHP, lamanya kurungan pengganti paling sedikit adalah satu hari dan paling lama enam bulan.

Ada pembagian pidana kurungan dan atau pidana kurungan pengganti dari pidana denda, yang seharusnya dijelaskan dalam penjelasan ataupun peraturan pelaksananya. UndangUndang Nomor 14 Tahun 2008 tentang Keterbukaan Informasi Publik tidak ada penjelasan mengenai siapa yang akan menjalani pidana kurungan apabila subjek tindak pidananya adalah Badan Publik, sehingga menimbulkan permasalahan tersendiri dalam hal menentukan siapa yang harus berkewajiban

bertanggungjawab dalam Badan Publik sebagai subjek tindak pidana.

\section{b. Tindak Pidana Keterbukaan}

\section{Informasi Publik Dalam}

\section{Kajian Perbandingan}

Di negara lain, kebebasan dalam memperoleh informasi diatur dalam peraturan perundangundangan berupa UndangUndang. Judul Undang-Undang Keterbukaan Informasi Publik di Negara lain: ${ }^{12}$

\begin{tabular}{|l|l|l|}
\hline $\begin{array}{l}\text { Negar } \\
\text { a }\end{array}$ & $\begin{array}{c}\text { Judul } \\
\text { Undang- } \\
\text { Undang }\end{array}$ & $\begin{array}{c}\text { Ketentuan } \\
\text { Pidana }\end{array}$ \\
\hline Japan & Versi & $\bullet$ Article 44 \\
& Inggris: & $\begin{array}{l}\text { Punitive } \\
\text { Provision }\end{array}$ \\
\hline
\end{tabular}

12 Soemarno Partodihardjo, Tanya Jawab Sekitar Undang-Undang No. 14 Tahun 2008 Tentang Keterbukaan Informasi Publik, 2009, Jakarta, Gramedia Pustaka, hal 95. 


\begin{tabular}{|c|c|c|}
\hline & $\begin{array}{l}\text { Concerning } \\
\text { Access to } \\
\text { Information } \\
\text { Held by the } \\
\text { Administrat } \\
\text { ive Organs } \\
\text { (1999) } \\
\text { Diterjemah } \\
\text { kan dalam } \\
\text { bahasa } \\
\text { Indonesia: } \\
\text { Undang- } \\
\text { Undang } \\
\text { Tentang } \\
\text { Akses ke } \\
\text { Informasi } \\
\text { yang } \\
\text { Berada di } \\
\text { Badan } \\
\text { Pemerintah } \\
\text { an }\end{array}$ & $\begin{array}{l}\text { The } \\
\text { person } \\
\text { who in } \\
\text { violation } \\
\text { of Article } \\
\text { 23, } \\
\text { paragraph } \\
\text { 8, } \\
\text { discloses } \\
\text { secrets } \\
\text { shall be } \\
\text { sentenced } \\
\text { to } \\
\text { maximum } \\
\text { of one } \\
\text { year of } \\
\text { imprison } \\
\text { ment with } \\
\text { hard } \\
\text { labor, or a } \\
\text { maximum } \\
\text { fine of } \\
\text { 300, 000 } \\
\text { yen } \\
\text { Di } \\
\text { terjemahkan } \\
\text { dalam bahasa } \\
\text { Indonesia: } \\
\text { "siapapun } \\
\text { yang } \\
\text { melanggar } \\
\text { Pasal } 23 \\
\text { ayat } 8 \\
\text { dengan } \\
\text { membuka } \\
\text { rahasia } \\
\text { dijatuhi } \\
\text { pidana } \\
\text { paling lama } \\
\text { satu tahun } \\
\text { penjara } \\
\text { dengan kerja } \\
\text { densa, atau paling } \\
\text { yenya } \\
\text { and }\end{array}$ \\
\hline $\begin{array}{l}\text { Thaila } \\
\text { nd }\end{array}$ & $\begin{array}{l}\text { The } \\
\text { Official } \\
\text { Information } \\
\text { Act (1997) } \\
\text { Diterjemah } \\
\text { kan : } \\
\text { Undang- } \\
\text { Undang } \\
\text { Informasi }\end{array}$ & $\begin{array}{l}\text { - Chapter } \\
\text { Section } 40 . \\
\text { "Any } \\
\text { person who } \\
\text { fails to } \\
\text { comply } \\
\text { with an } \\
\text { order of the } \\
\text { Board }\end{array}$ \\
\hline
\end{tabular}

\begin{tabular}{|c|c|}
\hline $\begin{array}{l}\text { Resmi } \\
\text { (1997) }\end{array}$ & 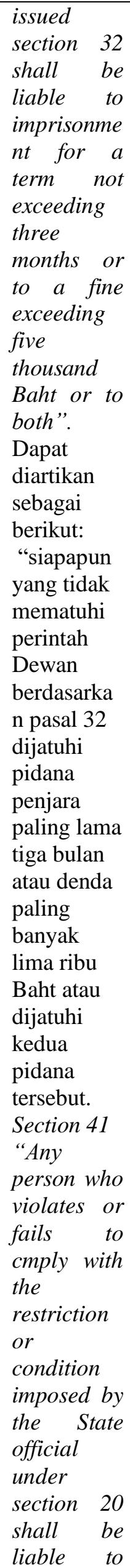 \\
\hline
\end{tabular}




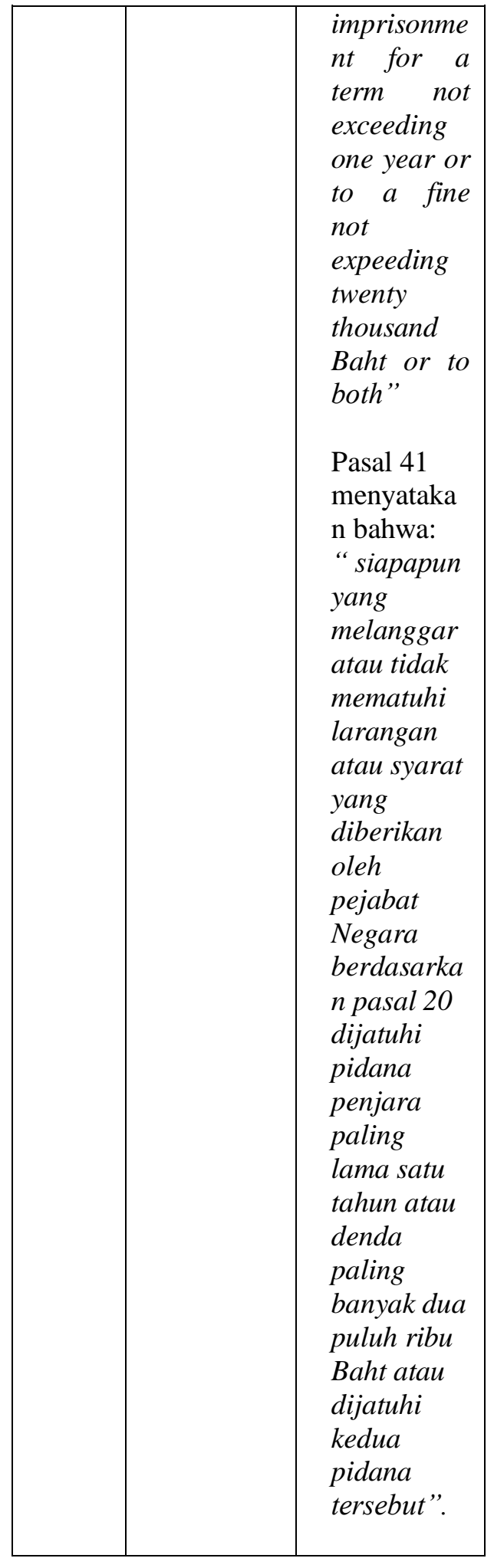

1) Perbandingan Tindak Pidana Keterbukaan Informasi Publik dengan Negara Jepang.

Kebebasan Informasi di Jepang sebelum diatur dalam lingkup nasional berupa Undang-Undang pada tahun 1999, sebelumnya berkembang dari instrumen hukum di tingkat lokal. Sejarah pembentukan UndangUndang Keterbukaan Informasi di Jepang dimulai sejak tahun 1960, karena adanya organisasi konsumen di Jepang, Shufu Rengokai yang meminta Kementerian Kesehatan dan Kesejahteraan Jepang memberikan informasi mengenai dampak pestisida dalam makanan, namun permintaan tersebut ditolak. Kemudian di tahun 1987 terjadi skandal suap perusahaan pembuat pesawat Tanaka yang ternyata tuntutan masyarakat Jepang untuk membuka informasi kebenaran skandal dimaksud ditolak pemerintah dengan alasan menjaga kerahasiaan pejabat publik.

Adanya dua kasus di atas, mendorong Japan Civil Liberty Union, di tahun 1979 mengusulkan Undang-Undang tata cara mendapat informasi yang baru pada tahun 1999 usulan tersebut diakomodasi dalam Law Concerning Access to Information Held By Administrative Organs. ${ }^{13}$ Dalam perspektif hukum, sebenarnya ada hal yang menarik berkenaan dengan jaminan atas hak kebebasan informasi di Jepang. Sebelum terbitnya Law Concerning Access to Information Held by

13 Koalisi Untuk Kebebasan Informasi, Kebebasan Informasi di Beberapa Negara, Jakarta: Koalisi untuk Kebebasan Informasi, 2003, hlm., 69. 


$\begin{array}{lr}\text { Administrative Organs, } \\ \text { ternyata beberapa daerah } \\ \text { di Jepang } & \text { sudah } \\ \text { menerbitkan } & \text { aturan } \\ \text { mengenai } & \text { kebebasan } \\ \text { informasi. }{ }^{14} & \end{array}$

\section{a) Perumusan Tindak}

Pidana Kebebasan

Informasi Publik di Jepang.

Ketentuan Pidana

Undang-Undang

Kebebasan Informasi

Jepang Versi Inggris

diatur dalam Article

44 Punitive Provision:

"the person who

in violation of

Article 23,

paragraph 8 ,

disclose secrets

shall be sentenced

to a maximum of

one year be

sentenced to a

maximum of one

year of

imprisonment with

hard labor, or a

maximum fine of

300,000 yen".

Diterjemahkan dalam

bahasa Indonesia:

"siapapun yang

melanggar Pasal

23 ayat 8 dengan

membuka rahasia

dijatuhi pidana

paling lama satu

tahun penjara

dengan kerja

paksa, atau denda

paling banyak

300.000 yen".

Undang-Undang

Kebebasan Informasi

Jepang tersebut diatas, rumusan tindak pidana menyebutkan unsur "sifat melawan hukum", meskipun unsur sifat melawan hukum tidak dicantumkan dengan tegas, namun rumusannya adalah:

- Melanggar;

- Membuka rahasia

b) Perumusan

Pertanggungjawaban

Pidana Dalam

Undang-Undang

Kebebasan Informasi di Jepang.

Undang-Undang

Akses Informasi di

Jepang, perumusan pertanggungjawaban pidana dapat dilihat dalam rumusan setiap pasalnya, yaitu "siapapun"

berorientasi pada "orang", dalam hal ini orang yang dimaksud adalah orang perorangan, orang yang menjabat Perdana Menteri, anggota Dewan Perwakilan Rakyat, Pejabat (tercantum dalam pasal per pasal.

c) Perumusan Pidana dan Pemidanaan Dalam UndangUndang Kebebasan Informasi di Jepang. Undang-Undang Akses Informasi Jepang masih tidak mencantumkan secara khusus hukuman bagi pejabat publik yang tidak mematuhi kewajibannya untuk membuka informasi, walaupun hal ini diatur tersendiri dalam Undang-Undang yang berkaitan dengan kepegawaian. Sanksi terhadap pejabat publik diatur dalam Undang-undang yang berkaitan dengan 
kepegawaian.

Walaupun demikian

dalam "Konferensi

Akses Informasi dan

Civil society" di

Jepang pada tanggal

13-14 april 2001, disepakati oleh

representasi dari 5

Negara (Filipina,

Korea, Indonesia,

Jepang dan Thailand).

Bahwa

keberadaan sanksi

bagi pejabat publik

yang melanggar

kewajibannya

merupakan hal yang

penting didalam

jaminan akses

informasi publik. $^{15}$

Keberadaan sanksi ini menjadi signifikan, sebab walaupun telah diupayakan agar menjadi bagian dari budaya administrasi di Jepang, tetapi sampai saat ini aparatur pemerintah masih sangat sulit untuk memberikan informasi kepada publik.

Ketiadaan sanksi bagi pejabat publik untuk membuka informasi menyebabkan masih sulitnya akses informasi didapatkan. Ditambah dengan sistem pengadilan yang cukup mahal dan memakan waktu lama menyebabkan hanya sedikit peminta informasi yang mampu saja yang bisa mendapatkan keadilan dalam sengketa informasinya melawan Negara. Hal ini berbeda dengan
Amerika yang memberikan hukuman dalam bentuk denda kepada pejabat Badan Publik yang tidak melaksanakan

kewajibannya, serta mewajibkan Negara untuk menanggung biaya pengacara, apabila seseorang memenangkan

perkaranya dalam Pengadilan

berdasarkan UndangUndang Kebebasan Informasi (Freedom Of Information Act), Tahun 1966.

Berdasarkan

Pasal 44 UndangUndang Kebebasan Informasi di Jepang, dimana sanksi pidana yang dijatuhkan berorientasi pada sistem pidana maksimal khusus 1 (satu) tahun penjara dengan kerja paksa, dengan alternatif pidana lain yakni berupa denda.

Diartikan bahwa, selain menjalani pidana penjara juga disertai dengan kerja paksa atau dengan adanya alternatif pidana denda sebagai pengganti pidana pokok berupa pidana penjara dan kerja paksa.

Pengaturan di dalam KUHP Jepang sendiri mengenal dua macam pidana, yaitu kerja paksa dan tanpa kerja paksa (imprisonment at or without forced labour) 


\begin{abstract}
- sedangkan dalam
Undang-Undang

Tentang Akses ke Informasi Yang

Berada di Badan

Pemerintahan di

Jepang, menggunakan pidana penjara dengan kerja paksa, maksudnya pelaku tindak pidana dikenai sanksi berupa pidana penjara dan sekaligus diwajibkan kerja paksa, atau denda paling banyak 300.000 yen, berarti meski bersifat kaku namun tetap ada alternatif sanksi pidana yang dijatuhkan.
\end{abstract}

2) Perbandingan Tindak Pidana Keterbukaan Informasi Publik dengan Negara Thailand.

a) Perumusan Tindak

Pidana

Dalam

Undang-Undang

Kebebasan Informasi di Thailand

Banyak kalangan menilai Thailand adalah negara pertama di Asia yang memiliki UndangUndang Kebebasan Informasi yang dikenal dengan UndangUndang Informasi Resmi.

Ketentuan pidana dalam Undang-Undang

Informasi Resmi Thailand (versi bahasa Inggris-Indonesia)diatur dalam: ${ }^{16}$

\section{CHAPTER VII}

Penalties

Section 40.

"Any person who fails to comply with an order of the Board issued section 32 shall be liable to imprisonment for a term not exceeding three months or to a fine exceeding five thousand Baht or to both".

Dapat diartikan sebagai berikut:

"siapapun yang

tidak mematuhi perintah Dewan berdasarkan pasal 32 dijatuhi pidana penjara paling lama tiga bulan atau denda paling banyak lima ribu Baht atau dijatuhi kedua pidana tersebut.

Pasal $32:{ }^{17}$

"Dewan berwenang memanggil siapapun untuk memberikan pernyataan atau menyerahkan barang, dokumen atau barang bukti untuk melengkapi pertimbangannya"

Section 41

"Any person who violates or fails to cmply with the restriction or condition imposed by the State official under section 20 shall be liable to imprisonment for a term not exceeding one year or to a fine not expeeding twenty thousand Baht or to both"

Pasal 41 menyatakan bahwa:

“ siapapun yang melanggar atau tidak mematuhi larangan atau syarat yang diberikan oleh pejabat Negara berdasarkan pasal 20 dijatuhi pidana penjara paling lama satu tahun atau denda paling banyak dua puluh ribu Baht atau dijatuhi kedua pidana tersebut".

Undang-Undang

Kebebasan Informasi tersebut diatas, rumusan

${ }^{16}$ Ibid., hlm., 231

${ }^{17}$ Ibid., hlm., 228. 
tindak pidana
menyebutkan unsur
"sifat melawan hukum",
meskipun unsur sifat
melawan hukum tidak
dicantumkan dengan
tegas, namun
rumusannya adalah:
- Melanggar;
- Tidak mematuhi
perintah;
Tidak mematuhi
larangan
Perihal tidak mematuhi perintah yang berdasar Pasal 20 yaitu: ${ }^{18}$

Dalam membuka informasi yang apabila dibuka dapat meminta

pertanggungjawaban

berdasarkan Undang-

Undang apapun, pejabat Negara wajib dibebaskan dari pertanggungjawaban itu apabila yang bersangkutan bertindak dengan iktikad baik dalam hal sebagai berikut:

(1) dalam hal informasi berdasarkan Pasal 15, apabila pejabat Negara bertindak sebagaiman mestinya sesuai Tata Tertib Perlindungan Kerahasiaan Resmi berdasarkan Pasal 16;

(2) dalam hal informasi berdasarkan pasal 15, apabila pejabat negara dalam jajaran yang ditetapkan oleh Peraturan Meneteri mengeluarkan perintah dibukanya informasi secara umum atau khusus kepada siapapun guna melindungi kepentingan yang lebih besar demi kepentingan umum, jiwa, fisik, seseorang dan perintah tersebut cukup beralasan, untuk tujuan ini, larangan atau syarat yang tepat dapat

${ }^{18}$ Ibid., hlm., 217.

diberlakukan terhadap penggunaan informasi tersebut.

Dibukanya informasi berdasarkan paragraf satu tidak dapat menjadi dasar untuk membebaskan badan Negara dari tanggung jawab hukum apabila terjadi sesuatu hal.

b) Perumusan

Pertanggungjawaban

Pidana Dalam

Undang-Undang

Kebebasan Informasi di Thailand.

Pengaturan di

KUHP Thailand, pertanggungjawaban

dapat dilihat dalam rumusan setiap pasalnya, yaitu berorientasi pada "orang" dalam hal ini orang yang dimaksud adalah orang perseorangan maupun anggota dewan. Sanksi pidana yang dijatuhkan berorientasi pada sistem pidana maksimal khusus 1 (satu) tahun penjara atau berupa sanksi denda dan bisa juga dengan alternatif sanksi pidana yakni dijatuhi sanksi keduanya baik berupa penjara dan denda dua puluh ribu Baht. Sanksi pidana yang dijatuhkan tergantung dari berat ringannya kesalahan.

c) Perumusan Pidana dan Pemidanaan

Dalam UndangUndang Kebebasan Informasi di Thailand.

Ketentuan pidana dalam Undang-Undang Informasi Resmi Thailand (versi bahasa 
Inggris-Indonesia)diatur dalam: ${ }^{19}$

\section{CHAPTER VII}

Penalties

Section 40.

"Any person who fails to comply with an order of the Board issued section 32 shall be liable to imprisonment for a term not exceeding three months or to a fine exceeding five thousand Baht or to both".

Dapat diartikan sebagai berikut:

"siapapun yang tidak mematuhi perintah Dewan berdasarkan pasal 32 dijatuhi pidana penjara paling lama tiga bulan atau denda paling banyak lima ribu Baht atau dijatuhi kedua pidana tersebut.

Section 41

"Any person who violates or fails to cmply with the restriction or condition imposed by the State official under section 20 shall be liable to imprisonment for a term not exceeding one year or to a fine not expeeding twenty thousand Baht or to both"

Pasal

menyatakan bahwa:

“ siapapun yang

melanggar atau tidak mematuhi larangan atau syarat yang diberikan oleh pejabat Negara berdasarkan pasal 20 dijatuhi pidana penjara paling lama satu tahun atau denda paling banyak dua puluh ribu Baht atau dijatuhi kedua pidana tersebut".

\section{KESIMPULAN}

${ }^{19}$ Ibid.
Kebijakan hukum pidana dalam menanggulangi tindak pidana keterbukaan informasi saat ini adalah dengan menggunakan KUHP sebagai ketentuan umum dan Undang-Undang Nomor 14 Tahun 2008 Tentang Keterbukaan Informasi Publik sebagai ketentuan khusus ( Lex specialis derrogat lex generalis ). Namun, dalam kenyataanya masih terdapat kelemahan, baik dalam perumusan tindak pidana seperti perumusan deliknya yang masih bersifat umum, tidak adanya kualifikasi tindak pidana, perumusan pertanggungjawaban pidananya yang tidak jelas dan terperinci, terhadap korporasi atau badan publik. Diperlukan peraturan perundang-undangan mengenai keterbukaan informasi yang lebih jelas, rinci, tegas, agar jelas batasan mengenai tindak pidana keterbukaan informasi, kemudian melakukan sosialisasi mengenai Undang-Undang Keterbukaan Informasi terutama berkaitan dengan sistem pemidanaan dan tujuan pedoman pemidanaannya serta upaya hukum berupa penegakan hukum terhadap tindak pidana keterbukaan informasi di masa yang akan datang sehingga pengaturannya jelas.

Dari ketentuan di atas, perumusan pidana yang dikenakan adalah pidana penjara sebagai pidana pokoknya dengan maksimal khusus satu tahun atau ada alternatif lainnya yaitu pidana denda atau hakim berhak menjatuhi kedua pidana tersebut secara bersamaan. Dilihat dari Undang-Undang Nomor 14 Tahun 2008 tentang Keterbukaan Informasi Publik di Indonesia serta perbandingan di Negara baik Negara Jepang maupun Negara Thailand, maka hendaknya kebijakan formulasi sistem pemidanaan tindak pidana keterbukaan informasi publik di Indonesia yang mencakup: 
Perumusan Tindak Pidana; MD, Mahfud Moh, 1999, Pergulatan Undang-Undang Nomor 14 Tahun Politik dan Hukum di Indonesia, Gama 2008 tentang Keterbukaan Media, Yogyakarta

Informasi Publik tidak Nawawi Arief, Barda, 2001, Masalah menyebutkan atau menentukan Penegakan Hukum dan Kebijakan kualifikasi delik sebagai kejahatan Penanggulangan Kejahatan, Citra atau pelanggaran. Seyogyanya Aditya Bakti, Bandung.

dalam Undang-Undang Nomor 14 Tahun 2008 tentang Keterbukaan Informasi Publik harus menentukan tindak pidana keterbukaan informasi publik secara jelas, dan perbuatan mana yang
dikualifikasikan sebagai tindak pidana keterbukaan informasi. Perumusan Pertanggungjawaban Pidana; Menurut perspektif yang akan datang, perumusan pertanggungjawaban tindak pidana keterbukaan informasi publik, harus jelas subjek tindak pidananya baik orang perseorangan, korporasi, badan hukum, maupun badan publik. Dalam Undang-Undang Keterbukaan Informasi Publik ini hendaknya diatur secara terperinci mengenai subjek tindak pidananya. Perumusan Pidana dan Pemidanaan; Undang-Undang Nomor 14 Tahun 2008 tentang Keterbukaan Informasi Publik dicantumkan bahwa bagi badan publik dikenakan pidana kurungan apabila melakukan tindak pidana keterbukaan informasi publik, dan hendaknya harus mencantumkan ketentuan pidana yang memuat apabila pidana denda sebagai alternatif pidana pokoknya tidak dilaksanakan, sebagai contoh seperti harus ada pidana pengganti denda, berupa sanksi administrasi yang berkaitan dengan pidana dan pemidanaan.

\section{DAFTAR PUSTAKA}

\section{Buku}

Muladi, 2002 Demokratisasi, Hak Asasi Manusia Dan Reformasi Hukum Di Indonesia, The Habibie Center, Jakarta. 2010, Kebijakan Pendekatan

Keilmuan dan Pendekatan Religius dalam Rangka Optimalisasi dan Reformasi Penegakan Hukum (Pidana) di Indonesia, Badan Penerbit Universitas Diponegoro, Semarang. , 2011, Tujuan dan Pedoman

Pemidanaan (Perspektif Pembaharuan \& Perbandingan Hukum Pidana), Penerbit Pustaka Magister, Semarang. 2010, Bunga Rampai Kebijakan Hukum Pidana, Prenada Media Group, Jakarta. 2010, Perbandingan Hukum Pidana, PT Raja Grafindo Persada, Jakarta. , 2010, Kapita Selekta Hukum Pidana, PT. Citra Aditya Bakti, Bandung. 2010, Perkembangan AsasAsas Hukum Pidana Indonesia (Perspektif Perbandingan Hukum Pidana), Badan Penerbit Universitas Diponegoro, Semarang. 2009, Kumpulan Hasil Seminar Hukum Nasional Ke I S/D VIII dan Konvensi Hukum Nasional 2008, Pustaka Magister, Semarang.

Sistem 2009, Perkembangan
Indonesia,
$\begin{aligned} & \text { Universitas } \\ & \text { Semarang. }\end{aligned}$

, 2009, Tujuan dan Pedoman Pemidanaan Perspektif Pembaharuan Hukum Pidana dan Perbandingan Beberapa Negara, Badan Penerbit Universitas Diponegoro, Semarang. , 2009, Sari Kuliah Hukum

Pidana Lanjut, Badan Penyediaan Bahan Kuliah 
Fakultas Hukum Universitas Diponegoro, Semarang. 2008, Mediasi Penal Penyelesaian Perkara di Luar Pengadilan, Pustaka Magister, Semarang.

2005, Pembaharuan

Hukum Pidana dalam Perspektif Kajian Perbandingan, PT Citra Aditya Bakti, Bandung. , 1999, Sari Kuliah Hukum

Pidana II, Badan Penyediaan Bahan Kuliah Fakultas Hukum Universitas Diponegoro, Semarang. 1998, Beberapa Aspek

Kebijakan Penegakan dan

Pengembangan Hukum Pidana, Citra Aditya Bakti, Bandung. , Tanpa Tahun, Reformasi sistem Peradilan (Sistem Penegakan Hukum di Indonesia), Badan Penerbit Universitas Diponegoro, Semarang. 1990, Pelengkap Bahan

Kuliah Hukum Pidana I, Yayasan Sudarto Fakultas Hukum Universitas Diponegoro, Semarang.

Soekanto, Soerjono dan Srimamudji, 2007, Penelitian Hukum Normatif: Suatu Tinjauan Singkat, Raja Grafindo Persada, Jakarta.

Soemitro, Ronny Hanitijo, 1990, Metodologi Penelitian Hukum dan Jurimetri, Ghalia Indonesia, Jakarta.

$\longrightarrow 1982$, Metodologi Penelitian Hukum, Ghalia Indonesia, Jakarta

Sudarto, 2006, Kapita Selekta Hukum Pidana, PT. Alumni Bandung.

Achmad Labib, 2009, Keterbukaan Informasi Publik Menuju Good Governance, Makalah yang disampaikan dalam seleksi calon anggota Komisi Informasi Provinsi Jawa Tengah, Semarang

JURNAL
Arif Widi Fatoni, Penyelesaian Sengketa Keterbukaan Informasi Publik Melalui Ajudikasi Dalam Undang-U No 14 Tahun 2008 Tentang Keterbukaan Informasi Publik, , Jurnal Ius Constituendum Vol 4 No 1, 2019, Semarang, Program Pasca Sarjana Universitas Semarang, hlm 80 .

Agus Sutiaman, Dadang Sugianan, Jimi Narotama M, Implementasi Kebijakan Keterbukaan Informasi Publik, Jurnal Jajian Komunikasi Vol 1 No 2, 2013, Bandung, Fakultas Ilmu Komunikasi Universitas Padjadajaran.

Edwin Nurdiansyah,, Keterbukaan Informasi Publik Sebagai Upaya Mewujudkan Transparansi bagi Masyarakat, Jurnal Bhinneka Tunggal Ika Vol 3 No 2, 2016, Palembang, Universitas Sriwijaya.

Noer Kristiyanto, Urgensi Keterbukaan Informasi Dalam Penyelenggaraan Pelayanan Publik, Jurnal Penelitian Hukum De Jure Vol 16 No 2, 2016, Jakarta, Badan Penelitian dan Pengembangan Hukum dan HAM, Kementerian Hukum dan HAM RI.

Slamet Haryanto, Kadi Sukarna, Peran Komisi Informasi Publik Dalam Proses Eksekusi Terhadap Putusan Sengketa Informasi Yang Berkekuatan Hukum Tetap Dalam tinjauan Undang-undang No 14 Tahun 2008 Tentang Keterbukaan Informasi Publik, Jurnal Ius Constituendum Vol 2 No 1, 2017, Semarang, Program Pasca Sarjana Universitas Semarang

\section{PERATURAN PERUNDANG- UNDANGAN}

Undang-Undang Dasar Negara Republik Indonesia Tahun 1945. 
Undang-Undang Republik Indonesia Nomor 39 Tahun 1999 Tentang Hak Asasi Manusia.

Kitab Undang-Undang Hukum Pidana (Wetboek van Strafrecht), oleh Moeljatno, Cet. 26, (Jakarta: PT Bumi Aksara, 2007).

Undang-Undang Republik Indonesia Nomor 14 Tahun 2008 tentang Keterbukaan Informasi (Semarang: Dinas Perhubungan Komunikasi dan Informatika Provinsi Jawa Tengah, 2009).

Undang-Undang Republik Indonesia Nomor 11 Tahun 2008 Tentang Informasi dan Transaksi Elektronik (Jakarta: Departemen Komunikasi dan Informatika Republik Indonesia, 2009).

Undang-Undang Tentang Akses ke Informasi yang berada di badan Pemerintahan (1999) Negara Jepang; $\quad$ Undang-Undang Informasi Resmi (1997) Negara Thailand. 